\title{
Dairy soil bacterial responses to nitrogen application in simulated Italian ryegrass and white clover pasture
}

\author{
Karl B. W. Svatos ${ }^{1,2,3 *}$ and Lynette K. Abbott ${ }^{1}$ \\ ${ }^{1}$ UWA School of Agriculture and Environment, The University of Western Australia, Perth 6009, Western Australia, Australia \\ ${ }^{2}$ School of Veterinary and Life Sciences, Murdoch University, Murdoch 6150, Western Australia, Australia \\ ${ }^{3}$ Agriculture and Food Division, Department of Primary Industries and Regional Development, South Perth 6151, Western Australia, Australia
}

\section{ABSTRACT}

Through clearing and use of fertilizer and legumes, areas of southwestern Australia's unique coastal sand plains can support relatively low-cost dairies. However, the ancient, highly weathered nature of the soils in this region makes the dairies susceptible to a range of threats, including nutrient leaching and erosion. Despite this, Western Australian dairy cows typically produce up to $5,500 \mathrm{~L}$ of milk per head annually supported by inorganic nitrogen $(\mathrm{N})$ fertilizer (commonly 50:50 urea and ammonium sulfate) at rates up to $<320 \mathrm{~kg}$ of $\mathrm{N} /$ ha per year. Where hotspots exist (up to $2,000 \mathrm{~kg}$ of $\mathrm{N} /$ ha per year), total $\mathrm{N}$ exceeds pasture requirements. We investigated plant and soil bacteria responses to $\mathrm{N}$ fertilizer rates consistent with Australian legislated production practices on dairy farms for pure and mixed swards of white clover (Trifolium repens) and Italian ryegrass (Lolium multiflorum) in a long-term pasture experiment in controlled glasshouse conditions. Although the soil bacterial community structure at phylum level was similar for white clover and Italian ryegrass, relative abundances of specific subgroups of bacteria differed among plant species according to the $\mathrm{N}$ fertilizer regimen. Marked increases in relative abundance of some bacterial phyla and subphyla indicated potential inhibition of $\mathrm{N}$ cycling, especially for $\mathrm{N}$ hotspots in soil. Ammonium concentration in soil was less correlated with dominance of some N-cycling bacterial phyla than was nitrate concentration. Changes in bacterial community structure related to altered nutrient cycling highlight the potential for considering this area of research in policy assessment frameworks related to nutrient loads in dairy soils, especially for $\mathrm{N}$.

Key words: nitrogen management, dairy pasture production, soil bacteria, clover, ryegrass

Received December 6, 2018.

Accepted June 1, 2019.

*Corresponding author: k.svatos@murdoch.edu.au

\section{INTRODUCTION}

Nutrient use efficiency, especially for nitrogen $(\mathrm{N})$, is facilitated by maximizing beneficial microbial processes in dairy soil leading to less nutrient leaching and runoff, lower costs, and better outcomes for farmers (Bolland and Guthridge, 2007b; Chen et al., 2018; Erisman et al., 2018). Australia's ecological sustainability legislation under which the dairy industry operates is outlined in Australia's Environment Protection and Biodiversity Conservation Act (Commonwealth Government of Australia, 1999). This legislation does not include the effects of microbial interactions associated with nutrient loads from the perspective of whole-ecosystem life cycle or environmental fate (Hemond and Fenchner-Levy, 2000; Svatos, 2018). Reports on soil quality, including N cycling, from New Zealand, the European Union, the United Kingdom, and the United States suggest that Australia's national sustainability legislation may need review in the light of new research linking production practices to microbial interactions in soil management with outcomes for ecosystems and primary producers (Anseeuw et al., 2012; Erisman et al., 2018). However, this area of research is significantly underrepresented in assessment frameworks and policy discussions, yet shows great potential (Bünemann et al., 2018).

The presence of legumes in dairy pastures can improve N use efficiency (van Eekeren et al., 2009; Lüscher et al., 2014), but excessive use of $\mathrm{N}$ fertilizer aimed at maximizing biomass for production gain is common practice in some places (Acosta-Martínez et al., 2010; Chapman et al., 2014; McDowell, 2017). The addition of high rates of $\mathrm{N}$ fertilizer to dairy pastures has potential to significantly reduce the effectiveness of soil microbial processes associated with efficient nutrient cycling, which may lead to overdose fertilization and downstream effects (Wepking et al., 2017; Duan et al., 2019). This may occur where excessive $\mathrm{N}$ accumulates and forms hotspots (e.g., urine patches), with total $\mathrm{N}$ entering ecosystems of up to $2,000 \mathrm{~kg} / \mathrm{ha}$ per year (Cameron et al., 2013; Chadwick et al., 2018). 
Plant species composition can influence functional patterns of bacterial biodiversity in grassland soils (Leff et al., 2015). There may be benefits for pasture soil management specific to pasture plant species and associated bacterial groups (e.g., $\mathrm{N}$ fixation facilitated by bacteria within Proteobacteria (Pham et al., 2017; Wall et al., 2019). Dominance or subdominance of particular groups of soil bacteria and their functions are now being categorized quantitatively via "omics" technologies. However, their role in soils cannot be determined by merely considering the dynamics and statistical significance of common gene database sequences or bacterial species due to multilayered biological evolutionary selection (Rosselli et al., 2016; Schöler et al., 2017; Denef, 2018). For microbiota inhabiting rhizospheres, selection acts simultaneously on genes, individuals, cells, groups, and the holobiont (the plant host with its extended microbiome; Garcia and Kao-Kniffin, 2018). It is essential to minimize bias surrounding extrapolation (the typical approach in species-specific gene functional analysis) and focus on increasing data reliability (Alberdi et al., 2018). By limiting assessments to analyses with a proven, classical, empirical basis, (e.g., $\mathrm{N}$ fixation; Tsoy et al., 2016) and by limiting functional prediction to already-characterized groups within traditional physiological classes in combination with long-term experiments, extrapolations can almost be eliminated (Contosta et al., 2015; Damaso et al., 2018; Schloter et al., 2018). We expected that persistent application of $\mathrm{N}$ fertilizer on the soil bacteria under swards of white clover (Trifolium repens) and Italian ryegrass (Lolium multiflorum; Van Dorland et al., 2008) grown in simulated glasshouse conditions would show changes in bacterial community structure related to altered nutrient cycling (Kasparovska et al., 2016; Melchior and Myer, 2018).

\section{MATERIALS AND METHODS}

This study examined the effect of $\mathrm{N}$ and pasture plant species on soil bacterial diversity and relative abundance at the end of a long-term $(8 \mathrm{mo})$ pasture sward experiment set up in a controlled $\left(20^{\circ} \mathrm{C}\right)$ glasshouse at The University of Western Australia (UWA).

We selected soil for this study from a dairy farm located in Cowaramup, Western Australia $\left(33^{\circ} 50^{\prime} 35.5^{\prime \prime} \mathrm{S}\right.$, $\left.115^{\circ} 11^{\prime} 38.0^{\prime \prime} \mathrm{E}\right)$ as part of a collaboration between Dairy Australia, UWA, and the Department of Primary Industries and Regional Development (McArthur, 2004; Dairy Australia, 2012). The soil collection methodology was consistent with the spatial sampling principles of Manter et al. (2010). We sampled the soil from the top $10 \mathrm{~cm}$ of the profile and transported it to UWA (at $0^{\circ} \mathrm{C}$ ) on the same day, and potted it on the next day.
Before potting, the soil was screened, thoroughly sieved over a $5-\mathrm{mm}$ fraction, and mixed to minimize bacterial spatial microclimate effects or bias and to ensure maximum achievable replication for all treatments. Soil bulk density was also determined (King, 1981; Bruand and Gilkes, 2002), as was the ratio of water to soil for watering up to (but not over) approximately $60 \%$ field capacity. The soil was placed in $10-\mathrm{cm}$ plastic-lined pots, and the surface was covered with plastic beads to minimize moisture loss (0.6 kg of soil/pot).

There were $3 \mathrm{~N}$ treatments, and each was calculated for elemental $\mathrm{N}$ using yearly known farmer application rates supplied to the Department of Primary Industries and Regional Development and Dairy Australia specific for dairy district practice and for the highest rate to simulate "hotspot" urine-like effects (Cameron et al., 2013). The 3 treatments were 0,180 , and $912 \mathrm{~kg}$ of N/ ha per year. The total amount received for each pot was the equivalent dose per week, calculated on daily doses of $0,0.5$, and $2.5 \mathrm{~kg}$ of $\mathrm{N} /$ ha per day for the 0 , 180 , and $912 \mathrm{~kg}$ of $\mathrm{N} / \mathrm{ha}$ per year treatments, respectively. The inorganic $\mathrm{N}$ fertilizer consisted of a 50:50 mix of urea and ammonium sulfate dissolved in aqueous solution. Nitrogen was applied weekly (in aliquots) and adjusted with additional water during the same fertilization event to maintain pots at approximately $60 \%$ field capacity.

The pasture species treatments were (1) Italian ryegrass (Lolium multiflorum), (2) white clover (Trifolium repens), and (3) Italian ryegrass and white clover sown at 50:50 (30 plants per pot; Moorby et al., 2009). There were 3 replicates of each treatment and 2 cycles of plant growth consisting of 2 generations of pasture plants grown to full maturity and harvested at the height of $1 \mathrm{~cm}$ above the soil level (harvested shoots were removed).

After the first harvest, the original seed stock seeds were resown into the same soil profile at the same seeding rate without significant soil disturbance after a few weeks. Fertilizer treatments were maintained throughout the 2 cycles. No fertilizer was added between growth cycles. At the final harvest (after $2 \times 4$-mo periods of continual growth), soil cores $\left(1 \mathrm{~cm}^{2}\right)$ from the top 0 to $5 \mathrm{~cm}$ of each pot were taken and placed in separate vials and stored in a freezer $\left(-20^{\circ} \mathrm{C}\right)$ for wet molecular chemistry, downstream sequencing, and bioinformatics.

At second harvest, shoots were harvested and dried, and the biomass was determined (shoot dry weight). Soil was oven-dried and analyzed by CSBP Laboratories in Bibra Lake, Western Australia, for (1) Colwell phosphorus $(\mathrm{mg} / \mathrm{kg}$ ) and Colwell potassium $(\mathrm{mg} / \mathrm{kg}$; methods $9 \mathrm{~B}$ and $18 \mathrm{~A} 1$, respectively; Rayment and Lyons, 2011), (2) KCl 40 sulfur (mg/kg; method 10D1, Rayment and Lyons, 2011), (3) organic carbon (\%; 
method 6A1, Rayment and Lyons, 2011), (4) nitrate $\mathrm{N}(\mathrm{mg} / \mathrm{kg})$ and ammonium $\mathrm{N}(\mathrm{mg} / \mathrm{kg}$; method $7 \mathrm{C} 2 \mathrm{~b}$, Rayment and Lyons, 2011), (5) electrical conductivity (dS/m; method 3A1, Rayment and Lyons, 2011), and (6) $\mathrm{pH}$ (H2O; method 4A1, Rayment and Lyons, 2011).

Genomic DNA was isolated from sample vials using the PowerSoil DNA Total Isolation Kit (Mobio Laboratories Inc., Solana Beach, CA). We optimized the manufacturer's protocol for our soil samples by using a bead-beating lysis procedure and by adding $200-\mu \mathrm{m}-$ diameter microbeads $(0.2 \mathrm{~g})$ to each sample vial (Abbott et al., 2012). The DNA extract quality and quantity were checked using a Nanodrop 1000 spectrophotometer (Thermo Fisher Scientific, Waltham, MA). Ribosomal 16S rRNA amplicons were generated via PCR (Suzuki and Giovannoni, 1996; Vestergaard et al., 2017), and the resultant PCR products were then prepared for sequencing and analysis (Klindworth et al., 2013; Vestergaard et al., 2017). Sequencing was performed using an Ion PGM OT 200 semiconductor (Thermo Fisher Scientific). Briefly, within R (Lucent Technologies, Murray Hill, NJ) packages and implemented through the Anaconda distribution (Anaconda, Austin, TX), Phyloseq (https://github.com/joey711/phyloseq), and biocLite (http://bioconductor.org/bioclite.r; Bioconductor, Huber et al., 2015), FastQ files were checked for accuracy against the latest available benchmark standards (mid-2018 release). For this process, we used Windows OS (Microsoft Corp., Redmond, WA) running Ubuntu 14.04 LTS (Canonical Ltd., London, UK) through a Virtual Box (Oracle Corporation, Redwood Shores, CA) virtual machine within a Python 3.6.5 reconfigured QIIME pipeline (Caporaso et al., 2010). FastQ files were then separately checked for low-quality reads before dereplication, annotation, and phylogenetic identification (Meyer et al., 2008; Lallias et al., 2015; Jovel et al., 2016). The phyla representing nonclassical taxonomic groups or less than $1 \%$ of the entire sample size were also removed, and the final taxonomic data sets were compiled (Abbott et al., 2012).

Data sets were analyzed as follows. First, a range of statistical ANOVA correlations were performed in GenStat (VSN International Ltd., Hemel Hempstead, UK) for significance based on the least significant differences (LSD). This included each $\mathrm{N}$ treatment and plant combination (shoot and soil data). Next, relationships between bacterial community diversity and relative abundance and soil data (eigenvectors) were assessed using canonical correspondence analysis in Microsoft Excel add-in XLSTAT ADA (Addinsoft, Paris, France). Then, pie chart representations were made for major taxonomic phyla across plant associations and $\mathrm{N}$ treatments. Next, histograms were made representing significant expanded phylum (class, order, and family) versus plant associations and $\mathrm{N}$ treatments. Finally, an assessment was then made in relation to all quantitative data sets with regard to the hypotheses (Lindgreen et al., 2016; Alberdi et al., 2018; Denef, 2018; Schloter et al., 2018).

\section{RESULTS}

\section{Effects of N Treatments on Pasture Plant Species (White Clover and Italian Ryegrass)}

Application of $\mathrm{N}$ to the plant swards increased $(P$ $<0.001$ ) shoot growth for both white clover and Italian ryegrass when grown alone. The highest level of $\mathrm{N}$ application influenced the ratio of white clover to Italian ryegrass in the mixed sward (Table 1). When the equivalent of $180 \mathrm{~kg}$ of N/ha per year was applied, the ratio of white clover to Italian ryegrass was reduced from 0.16 to 0.08 due to an increase in biomass of Italian ryegrass, but there was no change in white clover biomass compared with $0 \mathrm{~kg}$ of $\mathrm{N} /$ ha per year (Table 1). When $912 \mathrm{~kg}$ of $\mathrm{N} /$ ha per year was applied, white clover was completely outcompeted by Italian ryegrass (Table 1). Soil ammonium was higher under white clover than under Italian ryegrass (Table 1). Nitrate was very low in the soil for all treatments $(2 \mathrm{mg} / \mathrm{kg}$ of soil). Analysis of variance of soil data indicated that the application of $\mathrm{N}$ was highly significant $(P<0.001)$ in its effects on ammonium (LSD $=4.49 \mathrm{mg} / \mathrm{kg}$ ), sulfur $(\mathrm{LSD}=12.2 \mathrm{mg} / \mathrm{kg})$, potassium $(\mathrm{LSD}=18.8 \mathrm{mg} / \mathrm{kg})$, and $\mathrm{pH}$ (water; LSD $=0.16$; Figure 1$)$.

\section{Effects of N Application and Pasture Plant Species on Dominant Soil Bacterial Phyla and Physiologically Significant Subgroups (Order and Family)}

Italian ryegrass grown alone with the highest $\mathrm{N}$ application supported an increase in the relative abundance of Proteobacteria (Figure 2) and $\alpha$-Proteobacteria (Figure 3) and a slight decrease in the relative abundance of Acidobacteria, whereas the relative abundance of Actinobacteria and Firmicutes remained largely unaffected (Figure 2). For white clover grown alone with the highest $\mathrm{N}$ application, there was a decrease in the relative abundance of Proteobacteria and increases in the relative abundance of Firmicutes, Acidobacteria, and Actinobacteria (Figure 2). In soil from the mixed ryegrass and clover pasture sward, the relative abundance of Proteobacteria and Acidobacteria decreased slightly, whereas that of Actinobacteria and Firmicutes increased slightly with increasing $\mathrm{N}$ application. The 
Table 1. Dry weight shoot biomass (g/pot) of white clover and Italian ryegrass and soil ammonium $(\mathrm{mg}$ of $\mathrm{N} / \mathrm{kg}$ of soil; $\mathrm{n}=3 ; \pm \mathrm{SE})$ when grown in dairy soil for 4 mo with 1 control rate and $2 \mathrm{~N}$ treatment rates $(0,180$, and $912 \mathrm{~kg}$ of $\mathrm{N} / \mathrm{ha}$ per year) relative to the already-prevailing $\mathrm{N}$ soil concentrations, plus $5 \%$ least significant differences (LSD) for plant growth

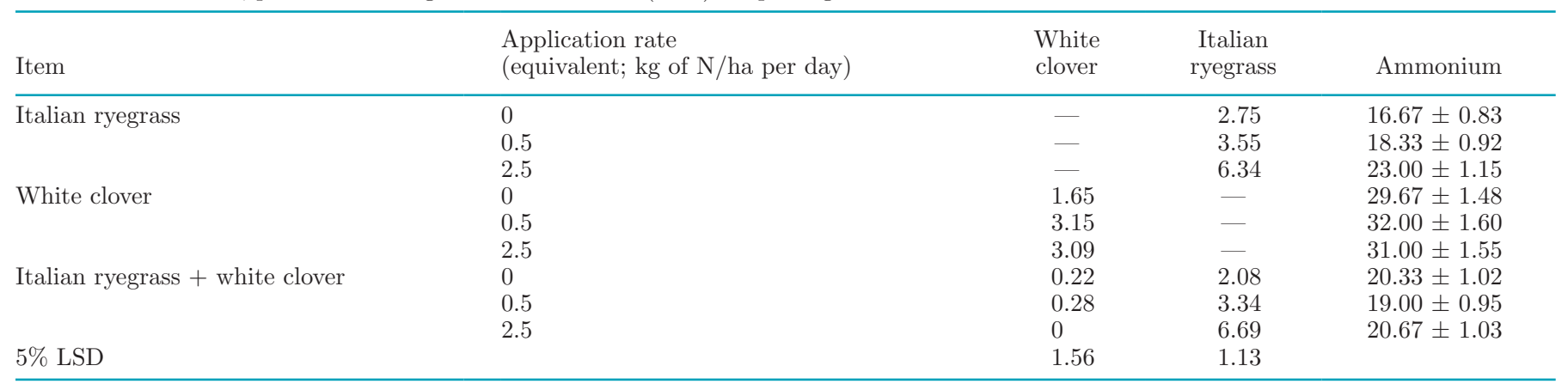

effects of $\mathrm{N}$ application and plant sward composition were minimal on bacterial groups that were recorded in the soil at low relative abundance.

Within Proteobacteria, application of $\mathrm{N}$ increased the relative abundance of Caulobacterales when white clover was grown alone, and the relative abundance of
Rhizobiales decreased (Figure 3). Within Firmicutes, N application to white clover reduced the relative abundance of some families of Baciliales and increased the relative abundance Clostridiaceae (Figure 4). Furthermore, there was an increase in the relative abundance of families Veillonellaceae and Peptococcaceae with N

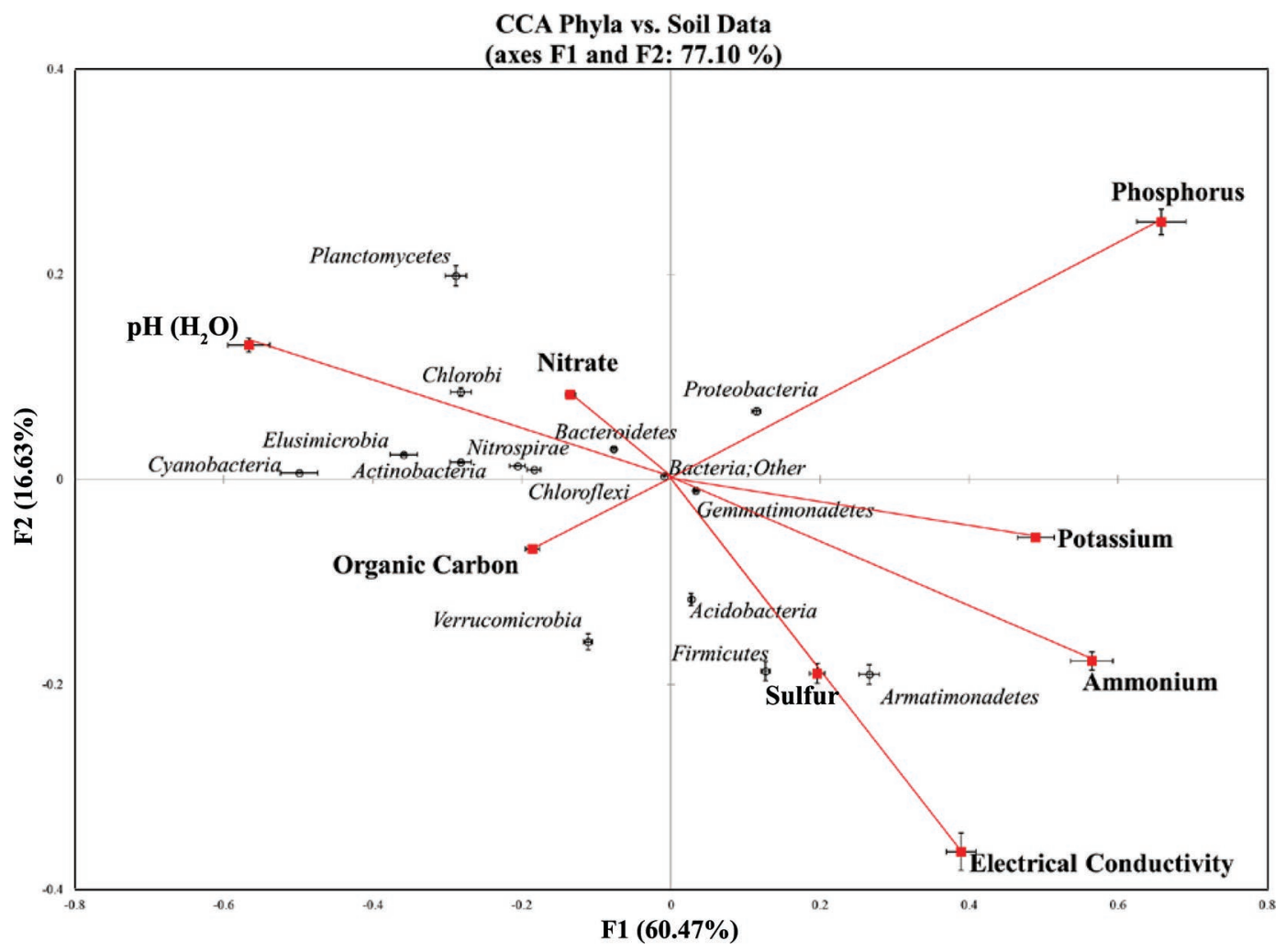

Figure 1. Canonical correspondence analysis (eigenvector analysis) of soil data versus sequenced $16 \mathrm{~S}$ rRNA dominant phyla (italicized) shows the variance that the dominant soil phyla have based on $\mathrm{N}$ treatments and plant species associations (including $5 \%$ SE bars). The proximity of phylum (open circles) to data vectors (bold) Colwell $\mathrm{P}(\mathrm{mg} / \mathrm{kg})$, Colwell $\mathrm{K}(\mathrm{mg} / \mathrm{kg}), \mathrm{KCl} 40 \mathrm{~S}$ ( $\mathrm{mg} / \mathrm{kg})$, organic carbon $(\%)$, nitrate $\mathrm{N}(\mathrm{mg} / \mathrm{kg})$, ammonium $\mathrm{N}(\mathrm{mg} / \mathrm{kg})$, electrical conductivity $(\mathrm{dS} / \mathrm{m})$, and $\mathrm{pH}\left(\mathrm{H}_{2} \mathrm{O}\right.$; red squares) indicates increasing correlation to that soil data point. Conversely, decreasing proximity to the data vectors indicates decreasing correlation (based on the soil data). The length of each vector indicates the significance of the relationship that the vector (soil property data) has to the overall community relative abundance and diversity makeup for the total sample size. In this canonical correspondence analysis (CCA), the first 2 axes of the eigenvector plots explain more than $77.1 \%$ of the total variance, which represents good sample separation about the (x, y) axis. 
application when white clover was grown alone (Figure $4)$.

\section{DISCUSSION}

For white clover and Italian ryegrass grown either alone or in combination on dairy farms, 50:50 urea and ammonium sulfate application in accordance with industry standards and legislation is likely to have a marked effect on soil bacterial communities related to nutrient uptake by plants in addition to overall plant biomass effects when $\mathrm{N}$ exceeds $180 \mathrm{~kg}$ of $\mathrm{N} / \mathrm{ha}$ per year (Iannetta et al., 2016). Recent studies that highlight some of the bacteria effects on soil and plants in a similar $\mathrm{N}$ concentration range include Wepking et al. (2017) and Duan et al. (2019). We also expect that the bacterial community changes are associated with $\mathrm{N}$ cycling changes; however, because quantifying $\mathrm{N}$ cycling and $\mathrm{N}$ cycling efficiency is not as simple as assessing $\mathrm{N}$ required for pasture plant biomass yield (Holly et al., 2018), many of the microbiological responses occurring in these production environments are often overlooked. However, they remain highly beneficial sources for improved management (Bünemann et al., 2018).

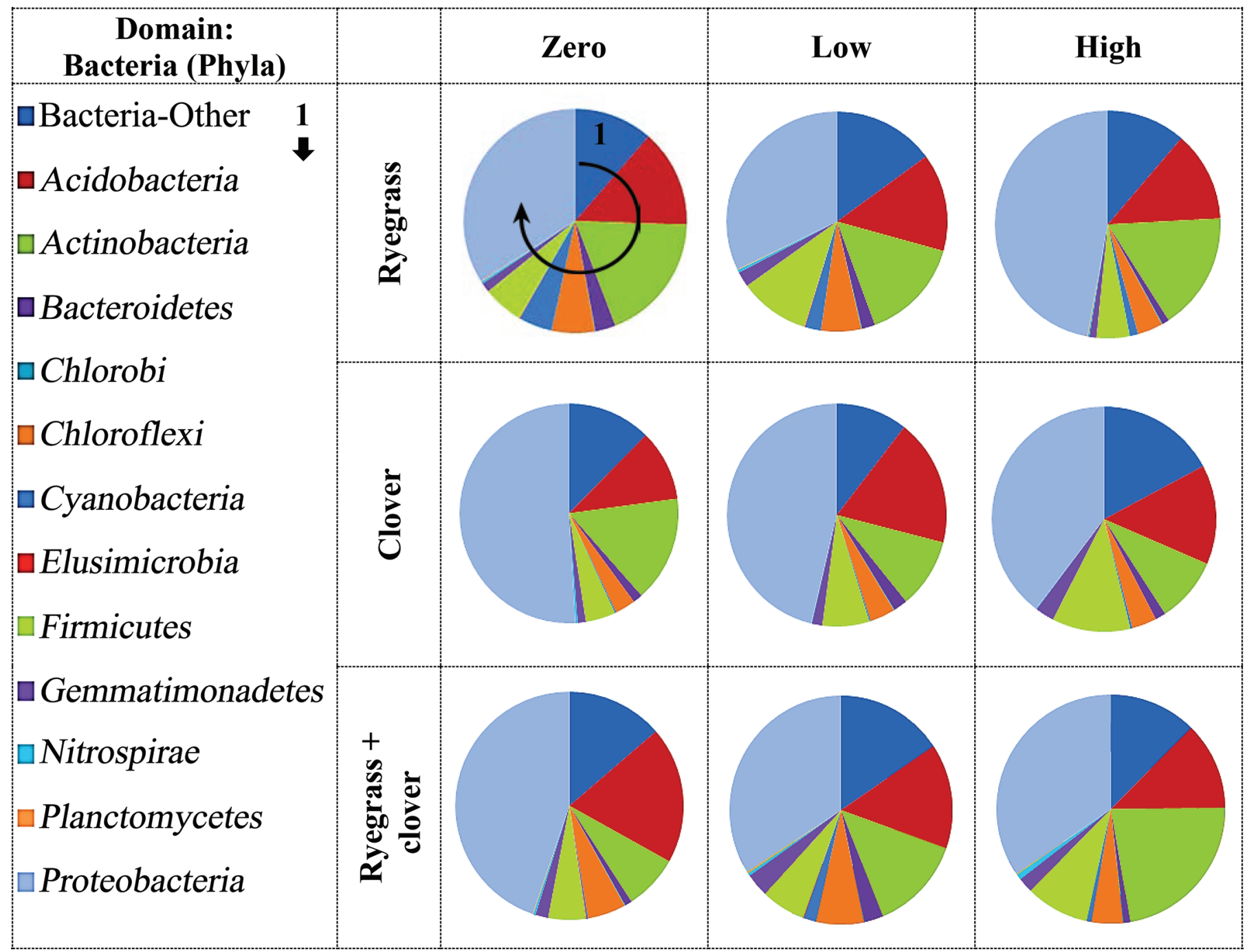

Figure 2. Treatment-specific relative abundance pie charts for domain: bacteria (phyla). Each pie chart indicates the relative abundances of the most dominant phyla present in each of the specific nitrogen $(\mathrm{N})$ treatment pots based on each plant association: Italian ryegrass (ryegrass), white clover (clover), and mixed (ryegrass + clover). Among all phyla displayed are 4 dominant phyla from all pots based on $\mathrm{N}$ treatment $(0,180$, and $912 \mathrm{~kg}$ of N/ha per year for zero, low, and high, respectively), including Proteobacteria, Acidobacteria, and Firmicutes, with lesser abundant groups including the equally distributed across all treatments "bacteria-other" making up total species diversity and relative abundance within the entire sample set (all plant association pots and all treatments). The number 1 in the first pie chart and at the top of the phyla key is for color identification. The arrows indicate how to correlate pie slices with the phyla (clockwise-downward manner). 
In this experiment, the concentration of ammonium under white clover was more significant in its effect on soil bacteria than nitrate (ammonia was less correlated than nitrate) based on eigenvector canonical correspondence analyses (Figure 1), which is consistent with the observations of Di et al. (2010), Chapman et al. (2014), and Sun et al. (2018). When $\mathrm{N}$ fertilizer was applied to clover grown alone, there was an increase in Rhizobiales $(\alpha-$ Proteobacteria) and Clostridia (Firmicutes; Minamisawa et al., 2004; Che et al., 2018). A dominance of alpha versus beta and gamma classes of Proteobacteria indicates oligotrophic soil conditions (İnceoğlu et al., 2011; Morrison et al., 2017) synonymous with N-limited environments (Senechkin et al., 2010; Ren et al., 2016). Because Rhizobiales was the most dominant order present across all treatments, it needs to be mentioned that the importance of their presence is consistently underrepresented in linking soil quality to soil function and ecosystem services (although not measured for functionality in our experiment; Albright et al., 2019; Wall et al., 2019).

There was a marked influence of the higher $\mathrm{N}$ application on pasture composition for white clover and Italian ryegrass grown together. Clover may mitigate production loss under increased stocking rate in sandy soils where constant $\mathrm{N}$ concentrations range from 180 up to (the maximum legislated) $320 \mathrm{~kg}$ of $\mathrm{N} /$ ha per year. Application rates above this range might trade off beneficial soil processes (especially around $\mathrm{N}$ hotspots) due to the inability of clover to compete with ryegrass (Kasparovska et al., 2016; Melchior and Myer, 2018). Interactions between $\mathrm{N}$ fertilizer, plant genotype, and soil bacterial community structure contribute to the effects of $\mathrm{N}$ on soil bacterial communities rather than $\mathrm{N}$ fertilizer alone.

The increase in the relative abundance of the Caulobacterales (within the $\beta$-Proteobacteria) with $\mathrm{N}$ application for white clover grown alone but not in com-

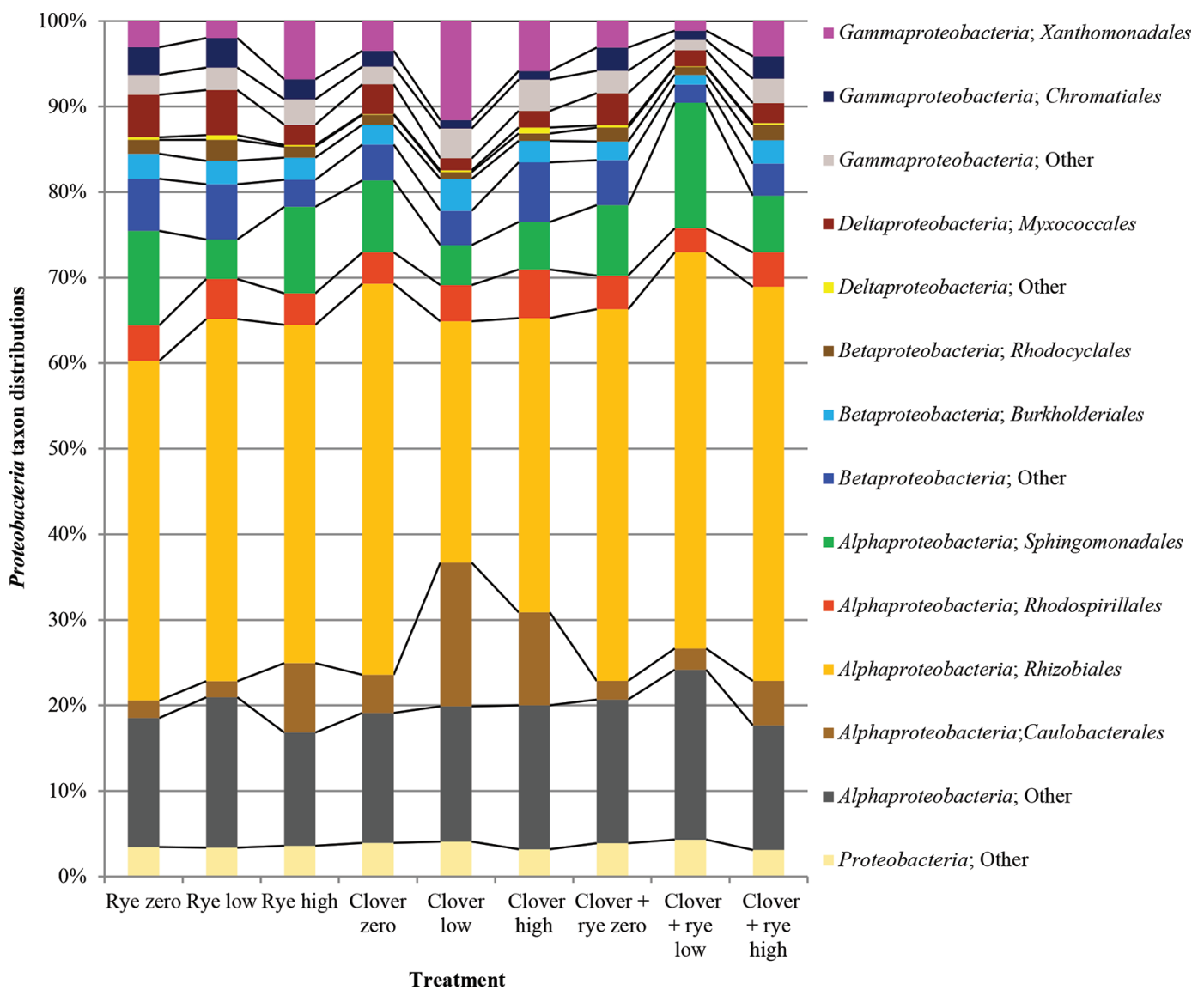

Figure 3. Diversity and relative abundance within phylum Proteobacteria in response to 3 nitrogen $(\mathrm{N})$ treatments $(0,180$, and $912 \mathrm{~kg}$ of $\mathrm{N} /$ ha per year for zero, low, and high, respectively) and 3 plant treatments [Italian ryegrass (rye), white clover (clover), and the combination of Italian ryegrass and white clover (clover + rye)]. The phyla displayed correspond to the colors shown on the right side of the chart. The order in which the phyla appear for the treatments is consistent. 


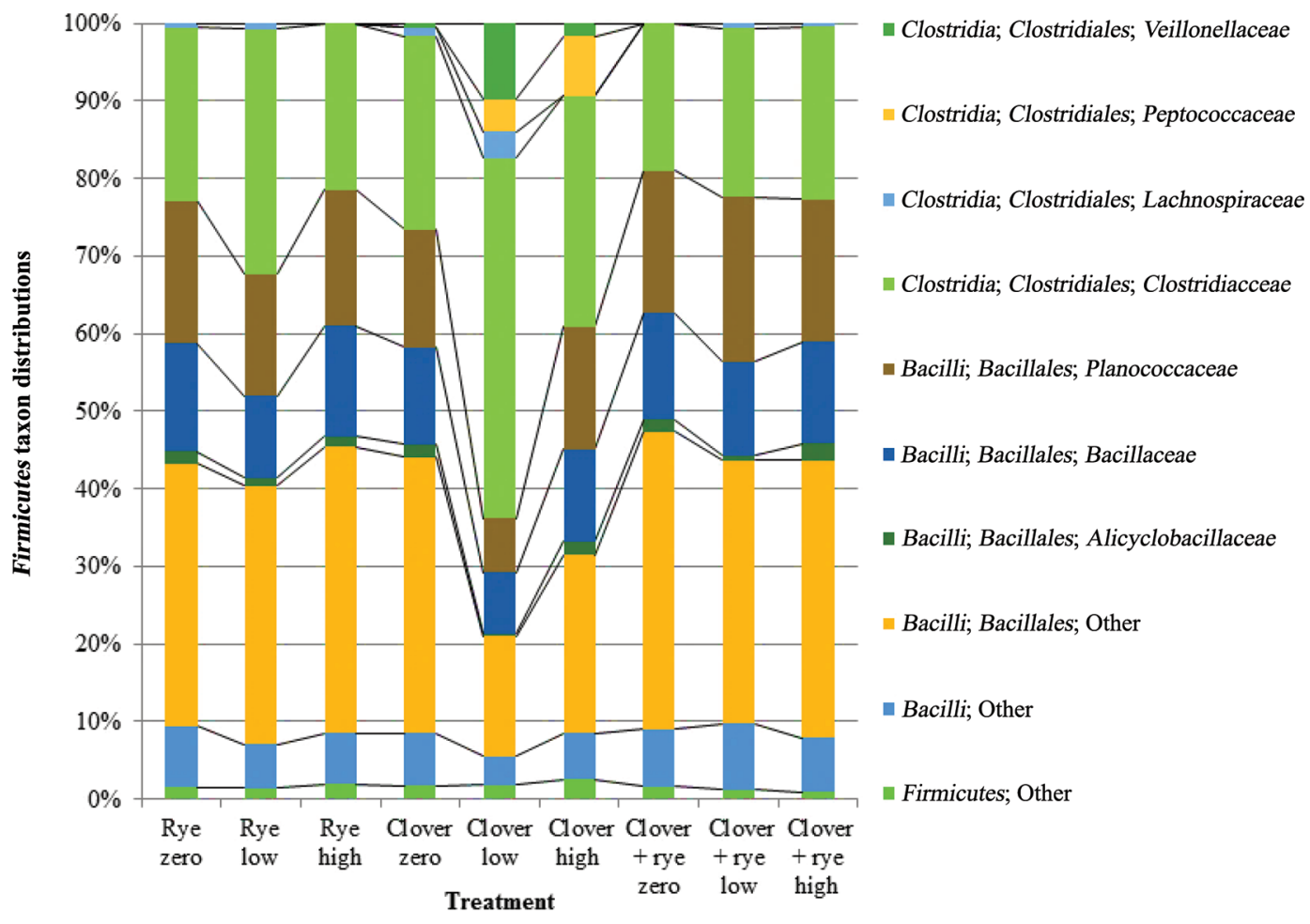

Figure 4. Diversity and relative abundance within phylum Firmicutes in response to 3 nitrogen (N) treatments $(0,180$, and $912 \mathrm{~kg}$ of N/ha per year for zero, low, and high, respectively) and 3 plant treatments [Italian ryegrass (rye), white clover (clover), and the combination of Italian ryegrass and white clover (clover + rye)]. The phyla displayed correspond to the colors shown on the right side of the chart. The order in which the phyla appear for the treatments is consistent.

bination with Italian ryegrass or Italian ryegrass alone corroborates a previous hypothesis that Caulobacterales may dominate N-fixing environments associated with clover (Zahran, 1999; Revell et al., 2012; McDowell, 2017). The ability of bacteria within Caulobacterales to regulate and transcribe orthologs (through speciation) to associate with $\mathrm{N}$ fixation processes is an essential consideration for dairy soils, especially for efficient use of $\mathrm{N}$ (including $\mathrm{N}$ fixation), as it may include previously unidentified biological pathways and needs investigation (Negreanu et al., 2012; Tsoy et al., 2016; Bünemann et al., 2018).

Bacteria in the order Clostridia have an essential role in N cycling (Heller, 1921; Wiegel, 2005). The relative abundance of Firmicutes was largely unaffected across all $\mathrm{N}$ and plant treatments except within the order Clostridia. Increases in the relative abundance of Veillonellaceae and Peptococcaceae after $\mathrm{N}$ application to white clover raise the possibility of resistance to acidified soil environments. The link between the increasing negative correlation between $\mathrm{N}$ and soil $\mathrm{pH}$ variation and the correlation between the presence of Firmicutes and organic carbon and $\mathrm{pH}$ supports this assumption (Figure 1). Veillonellaceae decreased again, indicating a buffering capacity threshold for $\mathrm{N}$ applied at a rate of
$180 \mathrm{~kg}$ of $\mathrm{N} /$ ha per year $<\mathrm{X}<320 \mathrm{~kg}$ of $\mathrm{N} /$ ha per year (Bolland and Guthridge, 2007a; Dairy Australia, 2012; Chadwick et al., 2018).

\section{CONCLUSIONS}

Nitrogen fertilizer applied at current levels to dairy pastures can alter the structure of soil bacterial communities as well as pasture plant dominance. We showed a marked effect of weekly applications of $\mathrm{N}$ fertilizer on the relative abundance of soil bacteria for swards of white clover (Trifolium repens) and Italian ryegrass (Lolium multiflorum) in a long-term glasshouse experiment. There is evidence to support our hypothesis that sustained and elevated $\mathrm{N}$ application alters the dominance of $\mathrm{N}$ cycling bacteria in this dairy soil, with potential for reduced $\mathrm{N}$ use efficiency, which could lead to increased prevalence of oligotrophic soil conditions (İnceoğlu et al., 2011; Morrison et al., 2017). Nitrogen applied to this dairy soil affected bacterial communities associated with 2 pasture plant species in a variety of ways (Gschwendtner et al., 2014). Characterization of bacteria from the orders Rhizobiales and Clostridia, within the $\alpha$-Proteobacteria and Firmicutes, respectively, may provide a litmus test for oligotrophic soil condi- 
tions in environments of poor nutrient binding (Ren et al., 2016; Tsoy et al., 2016). Further understanding of how $\mathrm{N}$ fertilizer use influences the functional aspects of bacterial communities associated with $\mathrm{N}$ cycling in dairy soils could assist in the development of better sustainability policies related to $\mathrm{N}$ application that takes into account group-level concepts of the soil microbiome and surrounding holobiont to minimize related risk.

\section{ACKNOWLEDGMENTS}

We acknowledge the contribution of the following people and industry groups. Dairy Australia (Southbank, Victoria) funded this research in collaboration with the University of Western Australia (Crawley, Western Australia). The Department of Primary Industry and Regional Development in Western Australia (previously Department of Agriculture and Food Western Australia, South Perth, Western Australia) provided logistical support. Zakaria Solaiman, Ian Waite, Richard Alcock, Sasha Jenkins, Michael Smirk, and Darryl Roberts (the University of Western Australia), Jim Cook (University of California, Davis), and Kim Angus (https:// www.facebook.com/ConsultKimToodyay, PO Box 379, Toodyay, Western Australia), provided valuable advice and editorial support during this study.

\section{REFERENCES}

Abbott, L., P. Mele, S. Jenkins, K. B. W. Svatos, D. Bougoure, H. Hayden, and I. Waite. 2012. Microbial community in response to nitrogen use in dairy soils. Page 193 in Proc. 5th Australasian Dairy Sci. Symposium: Dairy Production Systems, Australasian Dairy Science Symposium (Tallygaroopna, Victoria).

Acosta-Martínez, A., S. E. Dowd, Y. Sun, D. Wester, and V. Allen. 2010. Pyrosequencing analysis for characterization of soil bacterial populations as affected by an integrated livestock-cotton production system. Appl. Soil Ecol. 45:13-25. https://doi.org/10.1016/j .apsoil.2010.01.005.

Alberdi, A., O. Aizpurua, M. T. P. Gilbert, and K. Bohman. 2018. Scrutinizing key steps for reliable metabarcoding of environmental samples. Methods Ecol. Evol. 9:134-147. https://doi.org/10.1111/ 2041-210X.12849.

Albright, M. B. N., B. Timalsina, J. B. H. Martiny, and J. Dunbar. 2019. Comparative genomics of nitrogen cycling pathways in bacteria and archaea. Microb. Ecol. 77:597-606. https://doi.org/10 $.1007 / \mathrm{s} 00248-018-1239-4$.

Anseeuw, W., W. L. Alden, L. Cotula, and M. Taylor. 2012. Land rights and the rush for land: Findings of the Global Commercial Pressures on Land research project. International Land Coalition, Rome, Italy.

Bolland, M. D. A., and I. F. Guthridge. 2007a. Determining the fertilizer phosphorus requirements of intensively grazed dairy pastures in south-western Australia with or without adequate nitrogen fertilizer. Aust. J. Exp. Agric. 47:801-814. https://doi.org/10.1071/ EA05184.

Bolland, M. D. A., and I. F. Guthridge. 2007b. Responses of intensively grazed dairy pastures to applications of fertilizer nitrogen in south-western Australia. Aust. J. Exp. Agric. 47:927-941. https:/ /doi.org/10.1071/EA06014.
Bruand, A., and R. J. Gilkes. 2002. Subsoil bulk density and organic carbon stock in relation to land use for a Western Australian Sodosol. Aust. J. Soil Res. 40:999-1010. https://doi.org/10.1071/ SR01051.

Bünemann, E. K., G. Bongiorno, Z. Bai, R. E. Creamer, G. De Deyn, R. Goede, L. Fleskens, V. Geissen, T. W. Kuyper, P. Mäder, M. Pulleman, W. Sukkel, J. W. Groenigen, and L. Brussaard. 2018. Soil quality-A critical review. Soil Biol. Biochem. 120:105-125. https://doi.org/10.1071/SR01051.

Cameron, K. C., H. J. Di, and J. L. Moir. 2013. Nitrogen losses from the soil/plant system: A review. Ann. Appl. Biol. 162:145-173. https://doi.org/10.1111/aab.12014.

Caporaso, J. G., J. Kuczynski, J. Stombaugh, K. Bittinger, F. D. Bushman, E. K. Costello, N. Fierer, A. Gonzalez, J. K. Goodrich, J. I. Gordon, G. A. Huttley, S. T. Kelley, D. Knights, J. E. Koenig, R. E. Ley, C. A. Lozupone, D. McDonald, B. D. Muegge, M. Pirrung, J. Reeder, J. R. Sevinsky, P. J. Turnbaugh, W. A. Walters, J. Widmann, T. Yatsunenko, J. Zaneveld, and R. Knight. 2010. QIIME allows analysis of high-throughput community sequencing data. Nat. Methods 7:335-336. https://doi.org/10.1038/nmeth.f .303 .

Chadwick, D. R., L. M. Cardenas, M. S. Dhanoa, N. Donovan, T. Misselbrook, J. R. Williams, R. E. Thorman, K. L. McGeough, C. J. Watson, M. Bell, S. G. Anthony, and R. M. Rees. 2018. The contribution of cattle urine and dung to nitrous oxide emissions: Quantification of country specific emission factors and implications for national inventories. Sci. Total Environ. 635:607-617. https://doi .org/10.1016/j.scitotenv.2018.04.152.

Chapman, D. F., J. Hill, J. Tharmaraj, D. Beca, S. N. Kenny, and J. L. Jacobs. 2014. Increasing home-grown forage consumption and profit in non-irrigated dairy systems. 1. Rationale, systems design and management. Anim. Prod. Sci. 54:221-233. https://doi.org/ 10.1071/AN12295.

Che, R., Y. Deng, F. Wang, W. Wang, Z. Xu, Y. Hao, K. Xue, B. Zhang, L. Tang, H. Zhou, and X. Cui. 2018. Autotrophic and symbiotic diazotrophs dominate nitrogen-fixing communities in Tibetan grassland soils. Sci. Total Environ. 639:997-1006. https:/ /doi.org/10.1016/j.scitotenv.2018.05.238.

Chen, G. Q., S. Talebi, S. L. Gras, M. Weeks, and S. E. Kentish. 2018 A review of salty waste stream management in the Australian dairy industry. J. Environ. Manage. 224:406-413. https://doi.org/ 10.1016/j.jenvman.2018.07.056.

Commonwealth Government of Australia. 1999. Environment Protection and Biodiversity Conservation Act.

Contosta, A. R., S. D. Frey, and A. B. Cooper. 2015. Soil microbial communities vary as much over time as with chronic warming and nitrogen additions. Soil Biol. Biochem. 88:19-24. https://doi.org/ 10.1016/j.soilbio.2015.04.013.

Dairy Australia. 2012. Code of practice for dairyshed effluent-Western Australia. Accessed Mar. 3, 2012. https://www.dairyaustralia .com.au/western-dairy/farm/western-dairy-farm/fertiliser-feed -and-nutrients.

Damaso, N., J. Mendel, M. Mendoza, E. J. von Wettberg, G. Narasimhan, and D. E. Mills. 2018. Bioinformatics approach to assess the biogeographical patterns of soil communities: The utility for soil provenance. J. Forensic Sci. 63:1033-1042. https://doi.org/10 $.1111 / 1556-4029.13741$.

Denef, V. J. 2018. Peering into the genetic makeup of natural microbial populations using metagenomics. Pages 49-75 in Population Genomics: Microorganisms. M. Polz and O. Rajora, ed. Springer, Cham, Switzerland.

Di, H. J., K. C. Cameron, J. P. Shen, C. S. Winefield, M. O'Callaghan, S. Bowatte, and J. Z. He. 2010. Ammonia-oxidizing bacteria and archaea grow under contrasting soil nitrogen conditions. FEMS Microbiol. Ecol. 72:386-394. https://doi.org/10.1111/j.1574-6941 .2010.00861.x.

Duan, P., C. Fan, Q. Zhang, and Z. Xiong. 2019. Overdose fertilization induced ammonia-oxidizing archaea producing nitrous oxide in intensive vegetable fields. Sci. Total Environ. 650:1787-1794. https: /doi.org/10.1016/j.scitotenv.2018.09.341. 
Erisman, J. W., A. Leach, A. Bleeker, B. Atwell, L. Cattaneo, and J. Galloway. 2018. An integrated approach to a nitrogen use efficiency (NUE) indicator for the food production-consumption chain. Sustainability 10:925. https://doi.org/10.3390/su10040925.

Garcia, J., and J. Kao-Kniffin. 2018. Microbial group dynamics in plant rhizospheres and their implications on nutrient cycling. Front. Microbiol. 9:1516. https://doi.org/10.3389/fmicb.2018.01516.

Gschwendtner, S., J. Tejedor, C. Bimüller, M. Dannenmann, I. KögelKnabner, and M. Schlotter. 2014. Climate change induces shifts in abundance and activity pattern of bacteria and archaea catalyzing major transformation steps in nitrogen turnover in a soil from a mid-European beech forest. PLoS One 9:e114278. https://doi.org/ 10.1371/journal.pone.0114278.

Heller, H. H. 1921. Principles concerning the isolation of anaerobes: Studies in pathogenic anaerobes II. J. Bacteriol. 6:445-470.

Hemond, H. F., and E. J. Fenchner-Levy. 2000. Chemical Fate and Transport in the Environment. 2nd ed. Academic Press, Cambridge, MA.

Holly, M. A., P. J. Kleinman, R. B. Bryant, D. L. Bjorneberg, C. A. Rotz, J. M. Baker, M. V. Boggess, D. K. Brauer, R. Chintala, G. W. Feyereisen, J. D. Gamble, A. B. Leytem, K. F. Reed, P. A. Vadas, and H. M. Waldrip. 2018. Short communication: Identifying challenges and opportunities for improved nutrient management through the USDA's Dairy Agroecosystem Working Group. J. Dairy Sci. 101:6632-6641. https://doi.org/10.3168/jds.2017 $-13819$.

Iannetta, P. P., M. Young, J. Bachinger, G. Bergkvist, J. Doltra, R. J. Lopez-Bellido, M. Monti, V. A. Pappa, M. Reckling, C. F. E. Topp, R. L. Walker, R. M. Rees, C. A. Watson, E. K. James, G. R. Squire, and G. S. Begg. 2016. A comparative nitrogen balance and productivity analysis of legume and non-legume supported cropping systems: The potential role of biological nitrogen fixation. Front. Plant Sci. 7:1700. https://doi.org/10.3389/fpls.2016.01700.

İnceoğlu, Ö., W. A. Al-Soud, J. F. Salles, A. V. Semenov, and J. D. van Elsas. 2011. Comparative analysis of bacterial communities in a potato field as determined by pyrosequencing. PLoS One 6:e23321. https://doi.org/10.1371/journal.pone.0023321.

Jovel, J., J. Patterson, W. Wang, N. Hotte, S. O'Keefe, T. Mitchel, T. Perry, D. Kao, A. L. Mason, K. L. Madsen, and G. K. S. Wong. 2016. Characterization of the gut microbiome using $16 \mathrm{~S}$ or shotgun metagenomics. Front. Microbiol. 7:459. https://doi.org/10.3389/ fmicb.2016.00459.

Kasparovska, J., M. Pecinkova, K. Dadakova, I. Krizova, S. Hadrova, M. Lexa, J. Lochman, and T. Kasparovsky. 2016. Effects of isoflavone-enriched feed on the rumen microbiota in dairy cows. PLoS One 11:e0154642. https://doi.org/10.1371/journal.pone.0154642.

King, P. M. 1981. Comparison of methods for measuring severity of water repellence of sandy soils and assessment of some factors that affect its measurement. Aust. J. Soil Res. 19:275-285. https://doi .org/10.1071/SR9810275.

Klindworth, A., E. Pruesse, T. Schweer, J. Peplies, C. Quast, M. Horn, and F. O. Glöckner. 2013. Evaluation of general 16S ribosomal RNA gene PCR primers for classical and next-generation sequencing-based diversity studies. Nucleic Acids Res. 41:e1. https://doi .org/10.1093/nar/gks808.

Lallias, D., J. G. Hiddink, V. G. Fonseca, J. M. Gaspar, W. Sung, S. P. Neill, N. Barnes, T. Ferrero, N. Hall, P. J. D. Lambshead, M. Packer, W. K. Thomas, and S. Creer. 2015. Environmental metabarcoding reveals heterogeneous drivers of microbial eukaryote diversity in contrasting estuarine ecosystems. ISME J. 9:1208-1221. https://doi.org/10.1038/ismej.2014.213.

Leff, J. W., S. E. Jones, S. M. Prober, A. B. Barberán, E. T. Borer, J. L. Firn, W. S. Harpole, S. E. Hobbie, K. S. Hofmockel, J. M. H. Knops, R. L. McCulley, K. La Pierre, A. C. Risch, E. W. Seabloom, M. Schuetz, C. Steenbock, C. J. Stevens, and N. Fierer. 2015. Consistent responses of soil microbial communities to elevated nutrient inputs in grasslands across the globe. Proc. Natl. Acad. Sci. USA 112:10967-10972. https://doi.org/10.1073/pnas .1508382112 .
Lindgreen, S., K. L. Adair, and P. P. Gardner. 2016. An evaluation of the accuracy and speed of metagenome analysis tools. Sci. Rep. 6:19233. https://doi.org/10.1038/srep19233.

Lüscher, A., I. Mueller-Harvey, J. F. Soussana, R. M. Rees, and J. L. Peyraud. 2014. Potential of legume-based grassland-livestock systems in Europe: A review. Grass Forage Sci. 69:206-228. https: //doi.org/10.1111/gfs.12124.

Manter, D. K., T. L. Weir, and J. M. Vivanco. 2010. Sample pooling masks PCR-based estimates of soil microbial richness and community structure. Appl. Environ. Microbiol. 76:2086-2090. https:/ /doi.org/10.1128/AEM.03017-09.

McArthur, W. M. 2004. Reference Soils of South-Western Australia. Australian Society of Soil Science, Perth, Australia.

McDowell, R. W. 2017. Does variable rate irrigation decrease nutrient leaching losses from grazed dairy farming? Soil Use Manage. 33:530-537. https://doi.org/10.1111/sum.12363.

Melchior, E. A., and P. R. Myer. 2018. Fescue toxicosis and its influence on the rumen microbiome: Mitigation of production losses through clover isoflavones. J. Appl. Anim. Res. 46:1280-1288. https://doi.org/10.1080/09712119.2018.1496920.

Meyer, F., D. Paarmann, M. D'Souza, R. Olson, E. M. Glass, M. Kubal, T. Paczian, A. Rodriguez, R. Stevens, A. Wilke, J. Wilkening, and R. A. Edwards. 2008. The metagenomics RAST serverA public resource for the automatic phylogenetic and functional analysis of metagenomes. BMC Bioinformatics 9:386. https://doi .org/10.1186/1471-2105-9-386.

Minamisawa, K., K. Nishioka, T. Miyaki, B. Ye, T. Miyamoto, M. You, A. Saito, M. Saito, W. L. Barraquio, N. Teaumroong, T. Sein, and T. Sato. 2004. Anaerobic nitrogen-fixing consortia consisting of clostridia isolated from gramineous plants. Appl. Environ. Microbiol. 70:3096-3102. https://doi.org/10.1128/aem.70.5.3096 -3102.2004 .

Moorby, J. M., M. R. F. Lee, D. R. Davies, E. J. Kim, G. R. Nute, N. M. Ellis, and N. D. Scollan. 2009. Assessment of dietary ratios of red clover and grass silages on milk production and milk quality in dairy cows. J. Dairy Sci. 92:1148-1160. https://doi.org/10.3168/ jds.2008-1771.

Morrison, J. M., C. L. Murphy, K. Baker, R. M. Zamor, S. J. Nikolai, S. Wilder, M. S. Elshahed, and N. H. Youssef. 2017. Microbial communities mediating algal detritus turnover under anaerobic conditions. PeerJ 5:e2803. https://doi.org/10.7717/peerj.2803.

Negreanu, Y., Z. Pasternak, E. Jurkevitch, and E. Cytryn. 2012. Impact of treated wastewater irrigation on antibiotic resistance in agricultural soils. Environ. Sci. Technol. 46:4800-4808. https://doi .org/10.1021/es204665b.

Pham, V. T. K., H. Rediers, M. G. K. Ghequire, H. H. Hiep, R. D. Mot, J. Vanderleyden, and S. Spaepen. 2017. The plant growthpromoting effect of the nitrogen-fixing endophyte Pseudomonas stutzeri A15. Arch. Microbiol. 199:513-517. https://doi.org/10 .1007/s00203-016-1332-3.

Rayment, G. E., and D. J. Lyons. 2011. Soil Chemical Methods: Australasia. Vol. 3. CSIRO, Melbourne, Australia.

Ren, C., P. Sun, D. Kang, F. Zhao, Y. Feng, G. Ren, X. Han, and G. Yang. 2016. Responsiveness of soil nitrogen fractions and bacterial communities to afforestation in the Loess hilly region (LHR) of China. Sci. Rep. 6:28469. https://doi.org/10.1038/srep28469.

Revell, C. K., M. A. Ewing, and B. J. Nutt. 2012. Breeding and farming system opportunities for pasture legumes facing increasing climate variability in the south-west of Western Australia. Crop Pasture Sci. 63:840-847. https://doi.org/10.1071/CP12160.

Rosselli, R., O. Romoli, N. Vitulo, A. Vezzi, S. Campanaro, F. de Pascale, R. Schiavon, M. Tiarca, F. Poletto, G. Concheri, G. Valle, and A. Squartini. 2016. Direct 16S rRNA-seq from bacterial communities: A PCR-independent approach to simultaneously assess microbial diversity and functional activity potential of each taxon. Sci. Rep. 6:32165. https://doi.org/10.1038/srep32165.

Schloter, M., P. Nannipieri, S. J. Sørensen, and J. D. van Elsas. 2018. Microbial indicators for soil quality. Biol. Fertil. Soils 54:1-10. https://doi.org/10.1007/s00374-017-1248-3. 
Schöler, A., S. Jacquiod, G. Vestergaard, A. Schulz, and M. Schloter. 2017. Analysis of soil microbial communities based on amplicon sequencing of marker genes. Biol. Fertil. Soils 53:485-489. https:// doi.org/10.1007/s00374-017-1205-1.

Senechkin, I. V., A. G. C. L. Speksnijder, A. M. Semenov, A. H. C. van Bruggen, and S. L. van Overbe. 2010. Isolation and partial characterization of bacterial strains on low organic carbon medium from soils fertilized with different organic amendments. Microb. Ecol. 60:829-839. https://doi.org/10.1007/s00248-010-9670-1.

Sun, Y. F., J. P. Shen, C. J. Zhang, L. M. Zhang, W. M. Bai, Y. Fang, and J. Z. He. 2018. Responses of soil microbial community to nitrogen fertilizer and precipitation regimes in a semi-arid steppe. J. Soils Sediments 18:762-774. https://doi.org/10.1007/s11368-017 -1846-6.

Suzuki, M. T., and S. J. Giovannoni. 1996. Bias caused by template annealing in the amplification of mixtures of $16 \mathrm{~S}$ rRNA genes by PCR. Appl. Environ. Microbiol. 62:625-630.

Svatos, K. B. W. 2018. Commercial silicate phosphate sequestration and desorption leads to a gradual decline of aquatic systems. Environ. Sci. Pollut. Res. Int. 25:5386-5392. https://doi.org/10.1007 \%2Fs11356-017-0846-9.

Tsoy, O. V., D. A. Ravcheev, J. Čuklina, and M. S. Gelfand. 2016. Nitrogen fixation and molecular oxygen: Comparative genomic reconstruction of transcription regulation in Alphaproteobacteria. Front. Microbiol. 7:1343. https://doi.org/10.3389/fmicb.2016 .01343 .

Van Dorland, H. A., M. Kreuzer, H. Leuenberger, and H. Wettstein. 2008. Eating behavior of dairy cows offered fresh or ensiled white clover, red clover and ryegrass to choose from or in a mixture.
Appl. Anim. Behav. Sci. 111:205-221. https://doi.org/10.1016/j applanim.2007.06.018.

van Eekeren, N., D. van Liere, F. de Vries, M. Rutgers, R. de Goede, and L. Brussaard. 2009. A mixture of grass and clover combines the positive effects of both plant species on selected soil biota. Appl. Soil Ecol. 42:254-263. https://doi.org/10.1016/j.apsoil.2009 .04 .006 .

Vestergaard, G., S. Schulz, A. Schöler, and M. Schloter. 2017. Making big data smart-How to use metagenomics to understand soil quality. Biol. Fertil. Soils 53:479-484. https://doi.org/10.1007/ s00374-017-1191-3.

Wall, L. G., L. A. Gabbarini, A. E. Ferrari, J. P. Frene, J. Covelli, D. Reyna, and N. B. Robledo. 2019. Changes of paradigms in agriculture soil microbiology and new challenges in microbial ecology Acta Oecol. 95:68-73. https://doi.org/10.1016/j.actao.2019.02.00.

Wepking, C., B. Avera, B. Badgley, J. E. Barrett, J. Franklin, K. F. Knowlton, P. P. Ray, C. Smitherman, and M. S. Strickland. 2017. Exposure to dairy manure leads to greater antibiotic resistance and increased mass-specific respiration in soil microbial communities. Proc. Biol. Sci. 284:1851. https://doi.org/10.1098/rspb.2016 .2233 .

Wiegel, J. 2005. Genus Xanthobacter. Pages 555-556 in Bergey's Manual of Systematic Bacteriology: The Alpha-, Beta-, and Epsilon Proteobacteria. 2nd ed. Vol. 2. Part C. D. J Brenner, N. R. Krieg, and J. T. Staley, ed. Springer Verlag, New York, NY.

Zahran, H. H. 1999. Rhizobium-legume symbiosis and nitrogen fixation under severe conditions and in an arid climate. Microbiol. Mol. Biol. Rev. 63:968-989. 